\title{
Mathematical modeling for the annatto (Bixa orellana L.) seed drying process
}

\author{
Dyego da Costa Santos $^{1 *}$, Alexandre José de Melo Queiroz ${ }^{1}$, Rossana Maria Feitosa de Figueirêdo ${ }^{1}$, \\ and Emanuel Neto Alves de Oliveira ${ }^{1}$
}

\begin{abstract}
The pigment extraction process using annatto (Bixa orellana L.) seed produces a large amount of seed waste. Although most of these seeds are discarded, a number of studies report promising results with their use in animal feed. The good fiber content also suggests human nutrition applications, with possible incorporation in dietary foods. In the present study, annatto seeds derived from color extraction were dried, with and without the layer of oil left over from the process. Seeds were dried at $40,50,60$ and $70{ }^{\circ} \mathrm{C}$. Drying data were fitted to the Diffusion Approximation, Two Term, Midilli, Page and Thompson models. Drying was carried out up to a moisture content of approximately $5 \%$ wet basis. All the models studied exhibited adequate fit to the drying kinetics data of the annatto seeds, with coefficients of determination above 0.98 and root mean squared error (RMSE) below 1.0. Seeds with oil had longer drying times at 40 and $50{ }^{\circ} \mathrm{C}$ and shorter times at 60 and $70{ }^{\circ} \mathrm{C}$. The coefficients of diffusion showed values between $2.67 \times 10^{-11}$ and $9.50 \times 10^{-11} \mathrm{~m}^{2} \mathrm{~s}^{-1}$ and between $2.7 \times 10^{-11}$ and $6.21 \times 10^{-11} \mathrm{~m}^{2} \mathrm{~s}^{-1}$, while activation energies for liquid diffusions were 38.04 and $23.52 \mathrm{~kJ} \mathrm{~mol}^{-1}$, for residual seed drying with and without oil, respectively.
\end{abstract}

Key words: Agricultural waste, Bixa orellana, drying.

\section{INTRODUCTION}

The Bixa orellana $\mathrm{L}$. is a perennial tree of the family Bixaceae originally from tropical America. It is cultivated in several regions of Brazil and is popularly known as annatto. The fruits of this tree are abundant, with coloring ranging from yellow to dark red, in the form of capsules ovoid covered with long flexible spines and presenting 60-70 seeds inside (Kruppa et al., 2012). Annatto is very important for socioeconomic development in Northeastern Brazil, since $78.2 \%$ of its cultivation originates on family farms, under dryland conditions, with reduced costs compared to other cultivation methods (Anselmo et al., 2008).

The main product is the seed, whose coat is rich in bixin, a carotenoid coloring of wide interest in national and international markets. This interest, primarily in the food industry, is due to consumer demand for artificial coloring substitutes (Corlett et al., 2007; Santos et al., 2012). A large amount of seeds is produced by the pigment extraction process. Silva et al. (2006) report that annatto

${ }^{1}$ Universidade Federal de Campina Grande, Unidade Acadêmica de Engenharia Agrícola, Av. Aprígio Veloso, 882, Bodocongó, Campina Grande, Paraíba, Brasil.

*Corresponding author (dyego.csantos@gmail.com).

Received: 1 March 2013.

Accepted: 17 June 2013.

doi: $10.4067 /$ S0718-58392013000300017 seed waste has a bright red color and an external layer of soy oil, used as a vehicle to dilute bixin. According to Rêgo et al. (2010), approximately 2500 t of annatto subproduct are obtained in Brazil every year, mainly in the Northeast, where almost $97 \%$ of the subproduct is not reused.

A number of studies have been conducted using annatto seeds in animal feed (Silva et al., 2006; Ofosu et al., 2010; Rêgo et al., 2010). However, future research should be directed towards better reuse of these seeds, such as incorporating them into human food.

Drying is the most widely used commercial process to preserve foods because, compared to other long-term preservation methods, it is less costly and easier to operate (Alexandre et al., 2009). According to Martinazzo et al. (2010), drying consists of removing a large portion of the water initially contained in the product immediately after maturity, up to the maximum moisture content in which it can be stored for long periods, without significant loss of quality. The literature contains a number of studies on drying fresh annatto seeds (Guedes and Faria, 2000; Faria and Rocha, 2000); however, there are none on drying seeds derived from the color extraction industry.

Thus, the aim of the present study was to dry annatto seeds, with and without oil from the pigment extraction process, fit different mathematical models to experimental data, and determine the coefficients of diffusion and activation energies, under experimental conditions. 


\section{MATERIAL AND METHODS}

Annatto seeds, donated by the Marata food company located in the state of Sergipe, Brazil, were used (bulk density of $725.6 \mathrm{~kg} \mathrm{~m}^{-3}$ ). Seeds were steeped in soy oil used in the pigment extraction process. Seeds were processed in two ways, as follows: in the first, seeds were maintained with a layer of oil (Treatment 1), and in the second, the oil layer was removed by washing the seeds with a mixture of water and commercial detergent (Treatment 2).

The drying experiments were carried out in a completely randomized design with four replicates, each replicate with approximately $15 \mathrm{~g}$ of sample. To determine drying kinetics in thin layer, samples were weighed and dried in a forced-air circulation (Fanem, model 330) oven at 40, 50,60 , and $70{ }^{\circ} \mathrm{C}$ and air drying speed of approximately 1 $\mathrm{m} \mathrm{s}^{-1}$, with drying air in the horizontal direction; moisture loss was monitored until moisture content of the samples reached approximately 5\% wet basis (wb) $(5.26 \%$ dry basis $[\mathrm{db}])$.

Moisture ratios (MR) were calculated from weight loss data of the samples during drying. Equation [1] was used to calculate the moisture ratio:

$$
\mathrm{MR}=\mathrm{X}-\mathrm{X}_{\mathrm{e}} / \mathrm{X}_{\mathrm{i}}-\mathrm{X}_{\mathrm{e}}
$$

where $M R$ is moisture ratio (dimensionless), $X$ is moisture content at any time $\mathrm{t}(\mathrm{db}), X_{i}$ is initial moisture content $(\mathrm{db})$, and $X_{e}$ is equilibrium moisture content (db).

The Diffusion Approximation, Two Terms, Midilli, Page and Thompson mathematical models were fit to experimental data obtained in the drying process. Where $t$ is drying time (min), $k$ is constant of drying $\left(\mathrm{min}^{-1}\right), a, b$, $n$ and $q$ is models coefficients:

Diffusion Approach $\mathrm{MR}=\mathrm{a} \cdot \exp (-\mathrm{k} \cdot \mathrm{t})+(1-\mathrm{a}) \cdot \exp (-\mathrm{k} \cdot \mathrm{b} \cdot \mathrm{t})$ (Akpinar et al., 2008)

Two Term MR = a.exp(-k.t) + b.exp(-q.t)

(Jittanit, 2011)

Midilli $M R=a . \exp \left(-\mathrm{k} . \mathrm{t}^{\mathrm{n}}\right)+$ b.t (Midilli et al., 2002) [4]

Page MR $=\exp \left(-k \cdot t^{n}\right) \quad($ Roberts et al., 2008)

Thompson MR $=\exp \left(\left(-a-\left(a^{2}+4 . b . t\right)^{0,5}\right) / 2 . b\right)$

(Botelho et al., 2011)

The coefficient of determination $\left(\mathrm{R}^{2}\right)$ and root mean squared error (RMSE) were used as criteria to assess the fit of mathematical models to experimental data, according to Equation [7]:

$$
\mathrm{RMSE}=\left[\frac{1}{n} \sum_{i=1}^{n}\left(\mathrm{MR}_{\text {pred, } \mathrm{i}}-\mathrm{MR}_{\text {exp }, \mathrm{i}}\right)^{2}\right]^{\frac{1}{2}}
$$

where RMSE is dimensionless, $M R_{\text {pred }, i}$ is predicted moisture ratio (dimensionless), $M R_{\text {exp }, i}$ is experimental moisture ratio (dimensionless), and $n$ is number of observations.
Drying rates were calculated from moisture content data and drying times, according to Equation [8]:

$$
\mathrm{DR}=\mathrm{X}_{\mathrm{t}+\mathrm{dt}}-\mathrm{X}_{\mathrm{t}} / \mathrm{dt}
$$

where $D R$ is drying rate $\left(\mathrm{kg} \mathrm{kg}^{-1} \mathrm{~min}^{-1}\right), X_{t+d t}$ is moisture content at $\mathrm{t}+\mathrm{dt}\left(\mathrm{kg}\right.$ water $\left.\mathrm{kg}^{-1} \mathrm{DM}\right), X_{t}$ is moisture content at a specific time, and $t$ is drying time (min).

To determine the coefficient of diffusion, drying data of seeds with and without oil were fit to the mathematical model of liquid diffusion for the spherical geometric shape (Crank, 1975), with approximation of three terms (Equation [9]), maintaining the initial equivalent spherical diameter of seeds throughout the drying process. The model was used only with three terms, because for sufficiently long drying times the three terms $(i=3)$ in the series expansion gives a good estimate of the solution and with more three terms the resulted were the same.

$$
\mathrm{MR}=\frac{\mathrm{X}-\mathrm{Xe}}{\mathrm{Xi}-\mathrm{Xe}}=\frac{6}{\pi^{2}} \sum_{i=1}^{n} \frac{1}{\mathrm{n}^{2}} \exp \left[-\frac{\mathrm{n}^{2} \pi^{2} \mathrm{D}_{\mathrm{ef}} \mathrm{t}}{\mathrm{R}_{\mathrm{eq}}}\right]
$$

where $M R$ is moisture ratio (dimensionless), $D_{e f}$ is effective moisture diffusivity $\left(\mathrm{m}^{2} \mathrm{~s}^{-1}\right), n$ is number of terms, $R_{e q}$ is radius of the equivalent sphere (m), and $t$ is time (s).

To calculate the equivalent spherical diameter, the volume of 100 seeds (50 seeds with oil and 50 seeds without oil) was determined using the water displacement method (Mohsenin, 1986), and the equivalent diameter by the volume of a sphere (Equation [10]):

$$
\mathrm{V}_{\mathrm{g}}=\frac{4}{3} \pi \mathrm{r}^{3}
$$

where $V_{g}$ is grain volume $\left(\mathrm{m}^{3}\right)$, and $r$ is radius of the equivalent sphere $(\mathrm{m})$.

The relationship between the diffusion coefficient and drying temperature was described using the Arrheniustype equation (Equation [11]):

$$
\mathrm{D}=\mathrm{D}_{\mathrm{o}} \exp \left(-\frac{\mathrm{E}_{\mathrm{a}}}{\mathrm{RT}}\right)
$$

where $D_{o}$ is pre-exponential factor $\left(\mathrm{m}^{2} \mathrm{~s}^{-1}\right), E_{a}$ is activation energy $\left(\mathrm{J} \mathrm{mol}^{-1}\right), R$ is universal gas constant $\left(8.314 \mathrm{~J} \mathrm{~mol}^{-1}\right.$ $\left.{ }^{\circ} \mathrm{K}^{-1}\right)$, and $T$ is absolute temperature $\left({ }^{\circ} \mathrm{K}\right)$.

The coefficients of the Arrhenius-type equation were obtained by linearizing Equation [11] with the application of the logarithm:

$$
\mathrm{LnD}=\mathrm{LnD}_{\mathrm{o}}-\frac{\mathrm{E}_{\mathrm{a}}}{\mathrm{R}} \cdot \frac{1}{\mathrm{~T}}
$$

where $L n D_{o}$ is logarithmic of pre-exponential factor $\left(\mathrm{m}^{2}\right.$ $\left.\mathrm{s}^{-1}\right), E_{a}$ is activation energy $\left(\mathrm{J} \mathrm{mol}^{-1}\right), R$ is universal gas constant $\left(8.314 \mathrm{~J} \mathrm{~mol}^{-1}{ }^{\circ} \mathrm{K}^{-1}\right)$, and $T$ is absolute temperature $\left({ }^{\circ} \mathrm{K}\right)$.

The mathematical models were fit to the experimental data using Statistica software and non-linear regression, employing the Quasi-Newton method. The diffusion coefficients were submitted to ANOVA and means were compared by Tukey's test at 5\% probability, using Assistat software (Silva and Azevedo, 2002). 


\section{RESULTS AND DISCUSSION}

Figure 1 shows the experimental drying kinetics data of Treatment 1 and Treatment 2 samples at 40, 50, 60 and $70{ }^{\circ} \mathrm{C}$, expressed by moisture ratio as a function of drying time. The times required for Treatment 1 samples to reach the desired moisture content (approximately 5.0\% wb) were $5460 \mathrm{~min}$ at $40{ }^{\circ} \mathrm{C}, 3660 \mathrm{~min}$ at $50{ }^{\circ} \mathrm{C}, 780 \mathrm{~min}$ at $60{ }^{\circ} \mathrm{C}$ and $270 \mathrm{~min}$ at $70{ }^{\circ} \mathrm{C}$. Mean initial moisture content was $16.95 \pm 0.74 \% \mathrm{wb}(20.41 \% \mathrm{db})$ and the final content was $4.94 \pm 0.04 \% \mathrm{wb}(5.20 \% \mathrm{db})$. With respect to Treatment 2 samples, times spent in drying kinetics were $4020,2580,1380$ and $660 \mathrm{~min}$, for drying at 40,50, 60 and $70{ }^{\circ} \mathrm{C}$, respectively, with mean initial moisture content of $19.48 \pm 1.30 \% \mathrm{wb}(24.19 \% \mathrm{db})$ and final moisture content of $4.88 \pm 0.07 \% \mathrm{wb}(5.13 \% \mathrm{db})$.

The results maintain the expected dependence of drying velocity with the temperature used and corroborate several authors working with agricultural products, who reported the influence of temperature on drying velocity (Koyuncu et al., 2004; Doymaz, 2005; Corrêa et al., 2010; Costa et al., 2011; Reis et al., 2011; Tavakolipour, 2011; Jittanit, 2011; Ferreira et al., 2012; Diógenes et al., 2013; Santos et al., 2013).

Was performed a comparison between drying times of annatto seed samples with and without oil. Two
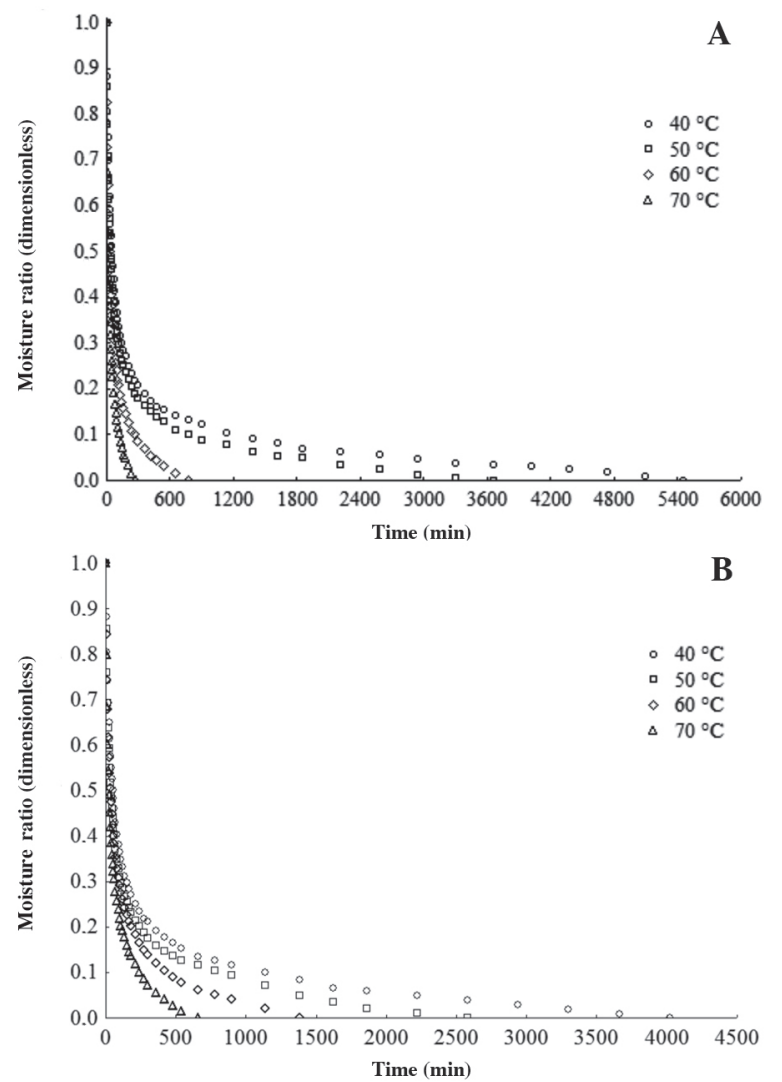

Figure 1. Drying curves of Treatment 1 (A) and Treatment 2 (B) samples at 40,50,60 and $70^{\circ} \mathrm{C}$. contrasting behaviors are observed depending on whether high or low temperatures were used. At 40 and $50{ }^{\circ} \mathrm{C}$ the oilless seeds dried nearly $30 \%$ faster than those with oil; at 60 and $70^{\circ} \mathrm{C}$, the opposite occurred, as samples with oil dried 77 and $144 \%$ faster than their oilless counterparts. One hypothesis to explain such behavior is that at lower temperatures the physical barrier represented by the film of oil hinders the release of water from the seeds into the environment. At higher temperatures, when shrinking in the surface layers of the seed becomes more important, the oil coating would prevent excessively rapid drying of the outer layers, reducing contraction and maintaining cell interstices for water migrating from inside the seed.

Lower drying times were reported by Tavakolipour (2011) when drying pistachio at $40,50,60$ and $70{ }^{\circ} \mathrm{C}$ and by Roberts et al. (2008), drying grape seeds 40,50 and $60{ }^{\circ} \mathrm{C}$ and drying speed of $1.5 \mathrm{~m} \mathrm{~s}^{-1}$. Longer drying times were recorded by Koyuncu et al. (2004) when drying walnuts at $40,50,60$ and $70{ }^{\circ} \mathrm{C}$ and drying speed of 0.5 and $1.0 \mathrm{~m} \mathrm{~s}^{-1}$, while Corrêa et al. (2010) obtained similar drying times with coffee beans at temperatures of 35,45 , and $55^{\circ} \mathrm{C}$.

Figure 2 shows the drying rates of Treatment 1 and Treatment 2 samples dried at $40,50,60$ and $70{ }^{\circ} \mathrm{C}$. No constant drying rate was found for either sample, given that drying occurred during periods of falling speed. These data corroborate the results obtained by Doymaz (2005), Lema et al. (2007), Doymaz (2009), and Ferreira et al.
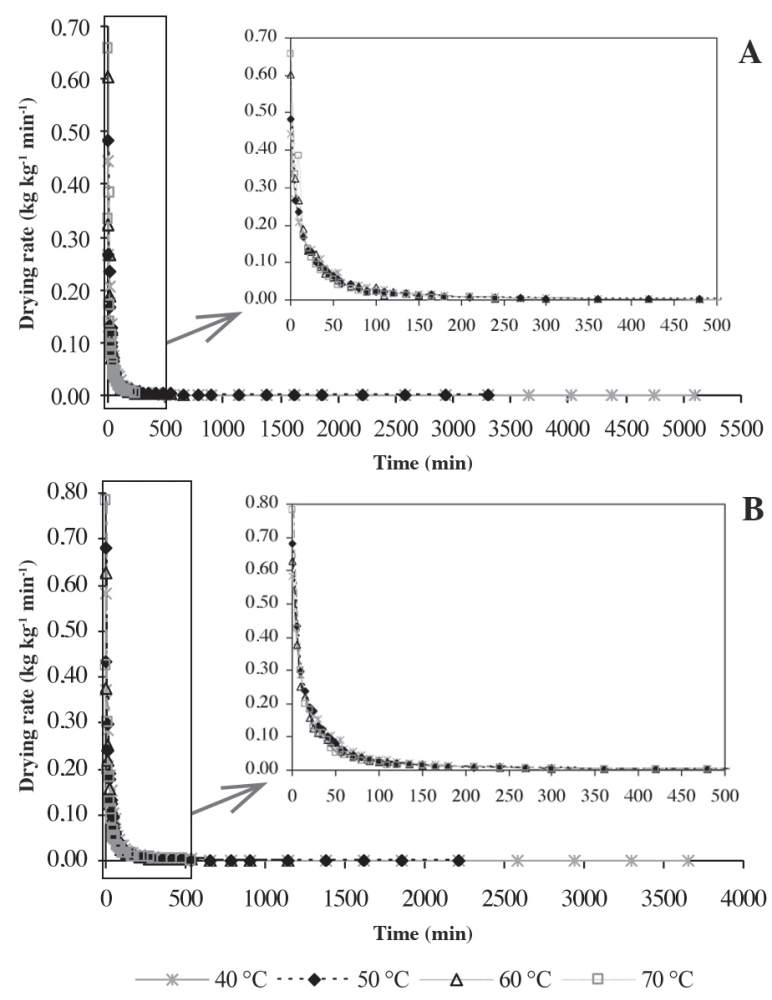

Figure 2. Drying rate of Treatment 1 (A) and Treatment 2 (B) samples at $40,50,60$ and $70{ }^{\circ} \mathrm{C}$. 
(2012), in a study on drying green beans, parsley, spinach leaves and grape bagasse, respectively. The drying rate decreases as the process continues, justified by the greater energy demand in products with lower moisture content and in the final drying stages. The Treatment 1 samples exhibited the lowest drying rates, possibly related to the presence of the oil layer, which can form a physical barrier on the seed surface, hindering moisture loss. With respect to drying temperatures, the highest rates were recorded at $70{ }^{\circ} \mathrm{C}\left(0.659 \mathrm{~kg} \mathrm{~kg}^{-1} \mathrm{~min}^{-1}\right.$ for Treatment 1 and $0.782 \mathrm{~kg} \mathrm{~kg}^{-1} \mathrm{~min}^{-1}$ for Treatment 2), whereas the lowest drying rates were found at a temperature of $40^{\circ} \mathrm{C}(0.445$ $\mathrm{kg} \mathrm{kg}^{-1} \mathrm{~min}^{-1}$ for Treatment 1 and $0.582 \mathrm{~kg} \mathrm{~kg}^{-1} \mathrm{~min}^{-1}$ for Treatment 2).

Tables 1 and 2 depict the fit parameters of Diffusion Approximation, Two Terms, Midilli, Page and Thompson mathematical models, drying kinetics data of Treatment 1 and Treatment 2 samples in the temperatures between 40 and $70{ }^{\circ} \mathrm{C}$ and their respective $\mathrm{R}^{2}$ and RMSE.

All the models assessed fit well to the drying data of Treatment 1 and Treatment 2 samples for the temperature range studied, with $\mathrm{R}^{2}$ above 0.98 and RMSE values below 0.1. The Diffusion Approximation and Two Terms models were used to estimate the drying kinetics curve of the samples, given that they display the highest $\mathrm{R}^{2}$ and lowest RMSE values.

Several authors also demonstrated good fit to the mathematical modeling when studying the drying kinetics of agricultural products, such as apples (Menges and Ertekin, 2006), rice grains (Hacihafizoglu et al., 2008), green beans (Doymaz, 2005), spinach leaves (Doymaz, 2009), chili peppers (Pontes et al., 2009), peas (Doymaz and Kocayigit, 2011), coffee beans (Resende et al., 2009;
2010; Corrêa et al., 2010), parsley (Lema et al., 2007), salvia (Radünz et al., 2010), pumpkin seeds (Jittanit, 2011), yellow lantern chili (Reis et al., 2011) and grape bagasse (Ferreira et al., 2012).

For the Treatment 1 samples (Table 1) the increase of the drying temperature caused an increase in the constants " $k$ " of Diffusion Approximation model, " $n$ " of Midilli and Page models and "b" of Diffusion Approximation and Thompson models. For the parameter "a" of Diffusion Approach and Midilli models, it was observed decrease with the increase of the drying air temperature. These data corroborate with Santos et al. (2013), that in studying the drying kinetics of the annato flour showed increases in the constants " $k$ ", " $n$ " and "b" and a reduction in the constant "a" of drying models fitted to the experimental values.

For Treatment 2 samples (Table 2) was observed behavior similar to that detected in the Treatment 1 samples, with increases in the constants " $k$ " of the Diffusion Approach model, "n" of the Midilli model and "b" of the Diffusion Approach and Thompson models. The constant "a" of Midilli model decreased with increasing of the drying air temperature. Jittanit (2011) reported of the drying kinetics of pumpkin seeds an increase of the constant " $\mathrm{k}$ " and reducing of the constant " $\mathrm{a}$ " in the models surveyed with increasing drying temperature. Diógenes et al. (2013) observed reductions in constant " $n$ " models fitted to experimental data, being opposite to that found in this work.

Corrêa et al. (2010) reported that the constant of drying "k" tends to increase because higher temperatures cause greater drying rates coming to an equilibrium moisture content in less time of submission of the sample to air

Table 1. Parameters of Diffusion Approximation, Two Terms, Midilli, Page and Thompson models with their respective coefficients of determination $\left(R^{2}\right)$ and root mean squared error (RMSE) of Treatment 1 drying.

\begin{tabular}{|c|c|c|c|c|c|c|c|c|}
\hline \multirow[b]{2}{*}{ Model } & \multirow[b]{2}{*}{ Temp. $\left({ }^{\circ} \mathrm{C}\right)$} & \multicolumn{5}{|c|}{ Parameters $^{1}$} & \multirow[b]{2}{*}{$\mathrm{R}^{2}$} & \multirow[b]{2}{*}{ RMSE } \\
\hline & & $\mathrm{a}$ & $\mathrm{b}$ & $\mathrm{k}$ & $\mathrm{n}$ & $\mathrm{q}$ & & \\
\hline \multirow[t]{4}{*}{ Diffusion Approach } & 40 & 0.6990 & 0.0399 & 0.0234 & - & - & 0.9928 & 0.0047 \\
\hline & 50 & 0.6731 & 0.0516 & 0.0310 & - & - & 0.9943 & 0.0042 \\
\hline & 60 & 0.5576 & 0.1120 & 0.0530 & - & - & 0.9976 & 0.0012 \\
\hline & 70 & 0.4887 & 0.1603 & 0.0860 & - & - & 0.9993 & 0.0020 \\
\hline \multirow[t]{4}{*}{ Two Term } & 40 & 0.2739 & 0.6659 & 0.0008 & - & 0.0194 & 0.9952 & 0.0145 \\
\hline & 50 & 0.3037 & 0.6465 & 0.0014 & - & 0.0266 & 0.9960 & 0.0122 \\
\hline & 60 & 0.5534 & 0.4191 & 0.0471 & - & 0.0056 & 0.9981 & 0.0049 \\
\hline & 70 & 0.5097 & 0.4876 & 0.0138 & - & 0.0852 & 0.9993 & 0.0015 \\
\hline \multirow[t]{4}{*}{ Midilli } & 40 & 1.0611 & 0.000007 & 0.1171 & 0.4625 & - & 0.9875 & 0.0218 \\
\hline & 50 & 1.0494 & 0.000008 & 0.1246 & 0.4727 & - & 0.9891 & 0.0163 \\
\hline & 60 & 1.0192 & 0.000019 & 0.0967 & 0.5874 & - & 0.9976 & 0.0038 \\
\hline & 70 & 1.0119 & -0.000006 & 0.0991 & 0.6655 & - & 0.9977 & 0.0018 \\
\hline \multirow[t]{4}{*}{ Page } & 40 & - & - & 0.1011 & 0.4776 & - & 0.9830 & 0.0733 \\
\hline & 50 & - & - & 0.1108 & 0.4853 & - & 0.9864 & 0.0495 \\
\hline & 60 & - & - & 0.0933 & 0.5897 & - & 0.9970 & 0.0154 \\
\hline & 70 & - & - & 0.0946 & 0.6753 & - & 0.9976 & 0.0043 \\
\hline \multirow[t]{4}{*}{ Thompson } & 40 & -0.3437 & 0.2087 & - & - & - & 0.9831 & 0.0866 \\
\hline & 50 & -0.3269 & 0.2271 & - & - & - & 0.9868 & 0.0583 \\
\hline & 60 & -1.4790 & 0.2983 & - & - & - & 0.9991 & 0.0059 \\
\hline & 70 & -2.7849 & 0.4067 & - & - & - & 0.9986 & 0.0062 \\
\hline
\end{tabular}

${ }^{1}$ In quadruplicate for each temperature. 
Table 2. Parameters of Diffusion Approximation, Two Terms, Midilli, Page and Thompson models with their respective coefficients of determination $\left(\mathbf{R}^{2}\right)$ and root mean squared error (RMSE) of Treatment 2 drying .

\begin{tabular}{|c|c|c|c|c|c|c|c|c|}
\hline \multirow[b]{2}{*}{ Model } & \multirow[b]{2}{*}{ Temp. $\left({ }^{\circ} \mathrm{C}\right)$} & \multicolumn{5}{|c|}{ Parameters $^{1}$} & \multirow[b]{2}{*}{$\mathrm{R}^{2}$} & \multirow[b]{2}{*}{ RMSE } \\
\hline & & $\mathrm{a}$ & $\mathrm{b}$ & $\mathrm{k}$ & $\mathrm{n}$ & $\mathrm{q}$ & & \\
\hline \multirow[t]{4}{*}{ Diffusion Approach } & 40 & 0.6690 & 0.0456 & 0.0262 & - & - & 0.9947 & 0.0002 \\
\hline & 50 & 0.6693 & 0.0498 & 0.0345 & - & - & 0.9953 & 0.0032 \\
\hline & 60 & 0.6080 & 0.0796 & 0.0417 & - & - & 0.9963 & 0.0004 \\
\hline & 70 & 0.5678 & 0.0985 & 0.0649 & - & - & 0.9983 & 0.0007 \\
\hline \multirow[t]{4}{*}{ Two Term } & 40 & 0.6413 & 0.3103 & 0.0226 & - & 0.0011 & 0.9963 & 0.0096 \\
\hline & 50 & 0.3154 & 0.6427 & 0.0016 & - & 0.0307 & 0.9966 & 0.0053 \\
\hline & 60 & 0.5922 & 0.3703 & 0.0366 & - & 0.0031 & 0.9973 & 0.0060 \\
\hline & 70 & 0.4210 & 0.5581 & 0.0062 & - & 0.0604 & 0.9986 & 0.0027 \\
\hline \multirow[t]{4}{*}{ Midilli } & 40 & 1.0575 & 0.000008 & 0.1175 & 0.4639 & - & 0.9879 & 0.0156 \\
\hline & 50 & 1.0475 & 0.000012 & 0.1335 & 0.4655 & - & 0.9870 & 0.0128 \\
\hline & 60 & 1.0301 & 0.000019 & 0.1086 & 0.5273 & - & 0.9948 & 0.0064 \\
\hline & 70 & 1.0188 & 0.000010 & 0.1210 & 0.5532 & - & 0.9966 & 0.0035 \\
\hline \multirow[t]{4}{*}{ Page } & 40 & - & - & 0.1023 & 0.4781 & - & 0.9845 & 0.0525 \\
\hline & 50 & - & - & 0.1213 & 0.4738 & - & 0.9842 & 0.0393 \\
\hline & 60 & - & - & 0.1026 & 0.5307 & - & 0.9934 & 0.0245 \\
\hline & 70 & - & - & 0.1156 & 0.5589 & - & 0.9963 & 0.0108 \\
\hline \multirow[t]{4}{*}{ Thompson } & 40 & -0.2882 & 0.2096 & - & - & - & 0.9844 & 0.0636 \\
\hline & 50 & -0.1772 & 0.2304 & - & - & - & 0.9835 & 0.0509 \\
\hline & 60 & -0.7315 & 0.2548 & - & - & - & 0.9956 & 0.0218 \\
\hline & 70 & -0.9917 & 0.3036 & - & - & - & 0.9981 & 0.0056 \\
\hline
\end{tabular}

${ }^{1}$ In quadruplicate for each temperature.

drying. The parameter " $n$ " has a moderating effect of time and corrects the errors likely due to the neglect of the internal resistance to moisture transfer (Guedes and Faria, 2000).

ANOVA showed a significant effect at $1 \%$ probability using the $\mathrm{F}$ test for diffusion coefficients of Treatment 1 and Treatment 2 samples obtained for drying at 40, 50,60 and $70{ }^{\circ} \mathrm{C}$. Tukey's test exhibited a significant difference between all the means at $5 \%$ probability.

Diffusion coefficient values increased with a rise in drying temperature, a phenomenon observed by other authors (Corrêa et al., 2010; Sousa et al., 2011; Costa et al., 2011; Faria et al., 2012; Ferreira et al., 2012). According to Corrêa et al. (2010), an increase in temperature promotes a decrease in water viscosity, which directly influences fluid outflow resistance. As such, its decline facilitates water molecule diffusion in the capillaries of the product.

The Treatment 1 samples exhibited diffusion coefficients with magnitudes of $2.67 \times 10^{-11}, 3.37 \times 10^{-11}$, $5.43 \times 10^{-11}$ and $9.50 \times 10^{-11} \mathrm{~m}^{2} \mathrm{~s}^{-1}$, for drying at 40, 50, 60 and $70{ }^{\circ} \mathrm{C}$, respectively. The Treatment 2 samples had diffusion coefficients of $2.7 \times 10^{-11}, 3.57 \times 10^{-11}, 4.13 \times$ $10^{-11}$ and $6.21 \times 10^{-11} \mathrm{~m}^{2} \mathrm{~s}^{-1}$, for drying at $40,50,60$ and $70{ }^{\circ} \mathrm{C}$, respectively. Similar diffusion coefficient values were reported by Sousa et al. (2011), who studied turnip seed drying in the temperatures between 30 and $70{ }^{\circ} \mathrm{C}$, and Faria et al. (2012), who investigated crambe seed drying in the temperatures between 30 and $70{ }^{\circ} \mathrm{C}$. Both had coefficients of $10^{-11} \mathrm{~m}^{2} \mathrm{~s}^{-1}$.

Diffusion coefficients increased linearly and their dependence on drying temperature was described by the Arrhenius equation (Figure 3). According to Faria et al. (2012), declining linearity demonstrates the uniform variation in drying rate within the temperature range under study.
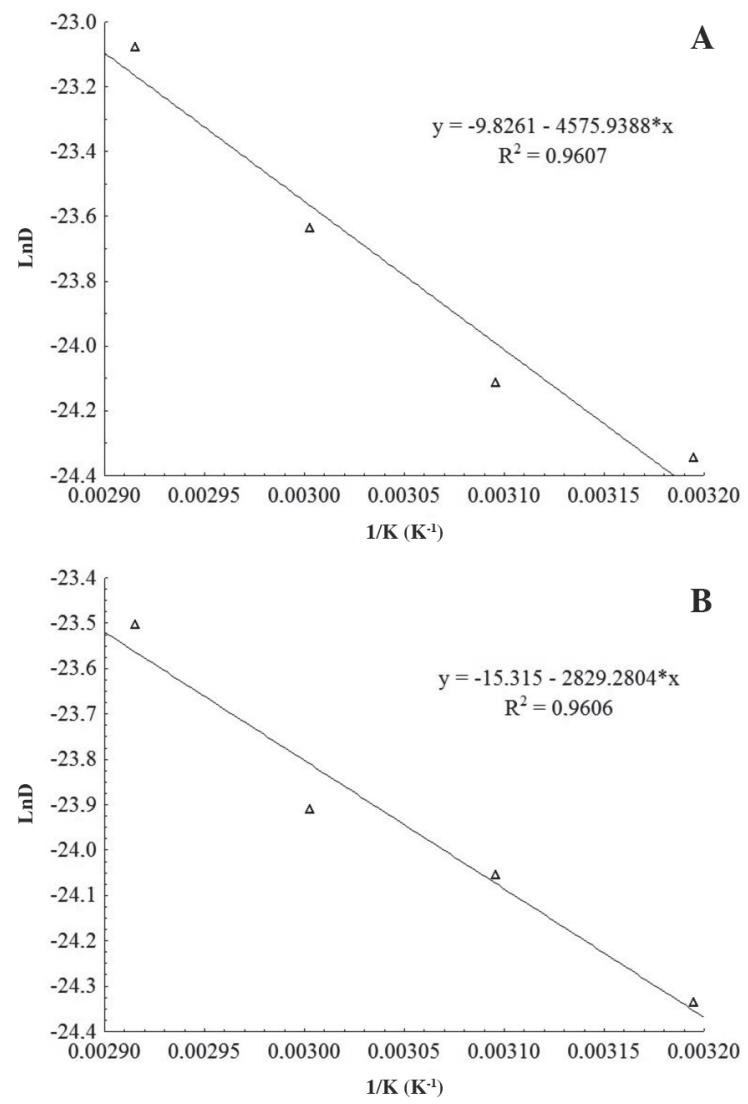

Figure 3. Arrhenius plot for the diffusion coefficient, as a function of drying temperature for Treatment 1 (A) and Treatment 2 (B) samples. 
Activation energies for liquid diffusion in the drying of Treatment 1 and Treatment 2 samples were 38.04 and $23.52 \mathrm{~kJ} \mathrm{~mol}^{-1}$, respectively. In accordance with Costa et al. (2011), in drying processes, the lower the activation energy the higher the moisture diffusiveness in the product. Therefore, Treatment 2 samples showed greater moisture diffusion with increased drying time, corroborating drying rate data. Corrêa et al. (2010) and Costa et al. (2011) reported similar activation energy to those of Treatment 1 samples, when drying coffee and crambe seeds, corresponding to 38.34 and $37.07 \mathrm{~kJ} \mathrm{~mol}^{-1}$, respectively. Sousa et al. (2011) and Ferreira et al. (2012) obtained similar activation energy to that of Treatment 2 samples, corresponding to 24.78 and $26.44 \mathrm{~kJ} \mathrm{~mol}^{-1}$ when studying turnip seed drying and grape bagasse, respectively.

\section{CONCLUSIONS}

All the models studied represented satisfactorily the drying kinetics of annatto seeds with and without oil at a temperature range $40-70{ }^{\circ} \mathrm{C}$ of drying air; within the models tested, the Diffusion Approximation and Two Terms drying models exhibited the best fit parameters with an $\mathrm{R}^{2} \geq 0.99$ and $\mathrm{RMSE} \leq 0.0145$. At lower temperatures (40 and $50{ }^{\circ} \mathrm{C}$ ), annatto seed samples with oil showed slower drying; at higher temperatures $\left(60\right.$ and $\left.70{ }^{\circ} \mathrm{C}\right)$ seeds with oil dried in a shorter period of time.

Diffusion coefficients increased with a rise in drying temperature, showed values with magnitudes of $10^{-11} \mathrm{~m}^{2}$ $\mathrm{s}^{-1}$. Samples without oil (Treatment 1) showed the greatest diffusivity in the temperatures of 40 and $50{ }^{\circ} \mathrm{C}$, while the samples with oil (Treatment 2) showed higher diffusivity at 60 and $70{ }^{\circ} \mathrm{C}$. The relationship between the diffusion coefficient and temperature can be described by the Arrhenius equation, which displays activation energies of 38.04 and $23.52 \mathrm{~kJ} \mathrm{~mol}^{-1}$ for samples of annatto seeds with and without oil, respectively.

\section{ACKNOWLEDGEMENT}

To Conselho Nacional de Desenvolvimento Científico e Tecnológico (CNPq) and Coordenação de Aperfeiçoamento de Pessoal de Nível Superior (CAPES) for the financial help and the food industry Maratá, for the donation of the annatto waste grains.

\section{LITERATURE CITED}

Akpinar, E.K. 2008. Mathematical modelling and experimental investigation on sun and solar drying of white mulberry. Journal of Mechanical Science and Technology 22:1544-1553.

Alexandre, H.V., J.P. Gomes, A.L. Barros Neto, F.L.H. Silva, and F.A.C. Almeida. 2009. Drying kinetics of sliced pineapple cv. pearl. Revista Brasileira de Produtos Agroindustriais 11(2):123128.
Anselmo, G.C.S., M.E.R.M. Cavalcanti-Mata, and E. Rodrigues. 2008. Hygroscopic behavior of annatto (Bixa orellana L.) dried extract. Ciência e Agrotecnologia 32:1888-1892.

Botelho, F.M., P.C. Corrêa, A.L.D. Goneli, M.A. Martins, F.E.A. Magalhães, and S.C. Campos. 2011. Periods of constant and falling-rate for infrared drying of carrot slices. Revista Brasileira de Engenharia Agrícola e Ambiental 15:845-852.

Corlett,F.M.F., A.C.S.A. Barros, and F.A. Villela.2007.Physiological quality of seeds of urucum stored in different environments and packings. Revista Brasileira de Sementes 29:148-158.

Corrêa, P.C., G.H.H. Oliveira, F.M. Botelho, A.L.D. Goneli, and F.M. Carvalho. 2010. Mathematical modeling and determination of thermodynamic properties of coffee (Coffea arabica L.) during the drying process. Revista Ceres 57:595-601.

Costa, L.M., O. Resende, K.A. Sousa, and D.N. Gonçalves. 2011. Effective diffusion coefficient and mathematical modeling for drying of crambe seeds. Revista Brasileira de Engenharia Agrícola e Ambiental 15:1089-1096.

Crank, J. 1975. The mathematics of diffusion. 414 p. Oxford University Press, London, UK.

Diógenes, A.M.G., A.J.M. Queiroz, R.M.F. Figueirêdo, e D.C. Santos. 2013. Cinética de secagem de grãos de abóbora. Revista Caatinga 26:71-80.

Doymaz, I. 2005. Drying behaviour of green beans. Journal of Food Engineering 69:161-165.

Doymaz, I. 2009. Thin-layer drying of spinach leaves in a convective dryer. Journal of Food Process Engineering 32:112-125.

Doymaz, I., and F. Kocayigit. 2011. Drying and rehydration behaviors of convection drying of green peas. Drying Technology 29:1273-1282.

Faria, L.J.G., and S.C.S. Rocha. 2000. Optimization of annatto (Bixa orellana L.) drying in fixed bed. Brazilian Journal of Chemical Engineering 17(4-7):483-496.

Faria, R.Q., I.R. Teixeira, I.A. Devilla, D.P.R. Ascheri, and O. Resende. 2012. Drying kinetics of crambe seeds. Revista Brasileira de Engenharia Agrícola e Ambiental 16:573-583.

Ferreira, L.F.D., M.R. Pirozi, A.M. Ramos, and J.A.M. Pereira. 2012. Mathematical modeling of thin-layer drying of fermented grape pomace. Pesquisa Agropecuária Brasileira 47:855-862.

Guedes, A.M.M., and L.J.G. Faria. 2000. Annatto (Bixa orellana L.) drying constant determination in convective fixed bed dryer. Revista Brasileira de Produtos Agroindustriais 2:73-86.

Hacihafizoglu, O., A. Cihan, and K. Kahveci. 2008. Mathematical modelling of drying of thin layer rough rice. Food and Bioproducts Processing 86:268-275.

Jittanit, W. 2011. Kinetics and temperature dependent moisture diffusivities of pumpkin seeds during drying. Kasetsart Journal: Natural Science 45:147-158.

Koyuncu, T., U. Serdar, and I. Tosun. 2004. Drying characteristics and energy requirement for dehydration of chestnuts (Castanea sativa Mill.) Journal of Food Engineering 62:165-168.

Kruppa, P.C., E.G. Fabri, e O.M.R. Russomanno. 2012. Importância dos fungos presentes nas sementes de urucum. Biológico 74(1): 51-54.

Lema, A., M. Pontin, A. Sanmartino, M. Ziletti, y M. Martinello. 2007. Características del proceso de secado en capa delgada del perejil. Avances en Energías Renovables y Medio Ambiente 11:875-882.

Martinazzo, A.P., E.C. Melo, P.C. Corrêa, and R.H.S. Santos. 2010. Mathematical modeling and quality parameters of lemon grass [Cymbopogon citratus (DC.) Stapf]. Revista Brasileira de Plantas Medicinais 12:488-498.

Menges, H.O., and C. Ertekin. 2006. Mathematical modeling of thin layer drying of Golden apples. Journal of Food Engineering 77:119-125.

Midilli, A., H. Kucuk, and Z. Yapar. 2002. A new model for single layer drying. Drying Technology 20:1503-1513.

Mohsenin, N.N. 1986. Physical properties of plant and animal materials. 841 p. Gordon and Breach Publishers, New York, USA. 
Ofosu, I.W.,E. Appiah-Nkansah,L. Owusu, F.B. Apea-Bah, I. Oduro, and W.O. Ellis. 2010. Formulation of annatto feed concentrate for layers and the evaluation of egg yolk color preference of consumers. Journal of Food Biochemistry 34:66-77.

Pontes, S.F.O., C.T. Santos, R.C.F. Bonomo, L.V. Pontes, and R.C.I. Fontan. 2009. Determination of the thin layers drying curves for smellpepper (Capsicum chinense) at varying temperatures. Revista Brasileira de Produtos Agroindustriais 11:143-148.

Radünz, L.L., A.J. Mossi, C.A. Zakrzevski, A.S. Amaral, and L. Grassmann. 2010. Drying kinetics analysis of sage leaves. Revista Brasileira de Engenharia Agrícola e Ambiental 14:979-986.

Rêgo, A.C., M.J.D. Cândido, E.S. Pereira, J.V. Feitosa, and M.M.T. Rêgo. 2010. Degradation of elephant grass silages with annatto by-product. Revista Ciência Agronômica 41:482-489.

Reis, R.C., L.S. Barbosa, M.L. Lima, J.S. Reis, I.A. Devilla, and D.P.R. Ascheri. 2011. Mathematical modeling of drying kinetics of pepper Cumarí do Pará. Revista Brasileira de Engenharia Agrícola e Ambiental 15:347-353.

Resende, O., R.V. Arcanjo, V.C. Siqueira, and S. Rodrigues. 2009. Mathematical modeling for drying coffee (Coffea canephora Pierre) berry clones in concrete yard. Acta Scientiarum. Agronomy 31:189-196.

Resende, O., S. Rodrigues, V.C. Siqueira, and R.V. Arcanjo. 2010. Kinetics of coffee berry clones drying (Coffea canephora Pierre) in ground pavement. Acta Amazônica 40:247-256.
Roberts, J.S., D.R. Kidd, and O. Padilla-Zakour. 2008. Drying kinetics of grape seeds. Journal of Food Engineering 89:460-465.

Santos, D.C., A.J.M. Queiroz, R.M.F. Figueirêdo, and E.N.A. Oliveira. 2012. Drying of waste grains flour of annatto by using solar energy. African Journal Agricultural Research 7:6281-6288.

Santos, D.C., A.J.M. Queiroz, R.M.F. Figueirêdo, e E.N.A. Oliveira 2013. Cinética de secagem de farinha de grãos residuais de urucum. Revista Brasileira de Engenharia Agrícola e Ambiental 17:223-231.

Silva, F.A.S., e C.A.V. Azevedo. 2002. Versão do programa computacional Assistat para o sistema operacional Windows. Revista Brasileira de Produtos Agroindustriais 4:71-78.

Silva, J.H.V., E.L. Silva, J. Jordão Filho, M.L.G. Ribeiro, and F.G.P Costa. 2006. Evaluating of annatto (Bixa orellana L.) seeds byproduct as yolk, skin, beak and ovary coloring of hens using two analytical methods. Ciência e Agrotecnologia 30:988-994.

Sousa, K.A., O. Resende, T.H. Chaves, and L.M. Costa. 2011. The drying kinetics of forage turnips (Raphanus sativus L.) Revista Ciência Agronômica 42:883-892.

Tavakolipour, H. 2011. Drying kinetics of pistachio nuts (Pistacia vera L.) World Applied Sciences Journal 12:1639-1646. 